\title{
Analyzing the Effects of E-Learning on Science Education
}

\author{
Hüseyin Çevik \\ Ankara Directorate of National Education, Turkey, cevik1979@gmail.com
}

Tayyip Duman

Prof., Bozok University, Faculty of Education, Turkey, tayip.duman@bozok.edu.tr

This study aims to determine the effects of morpa campus, a practice of e-learning on the science learning in the primary level in terms of primary school teachers' views. Qualitative research method was used in this research. The sample of the study is composed of 16 teachers that use Morpa campus. In order to get their views about Morpa campus, open-ended semi-structured interview questions were prepared and applied. Content analysis was used in this study. According to the results of the study, it has appeared that Morpa Campus is compatible with the main acquisitions of the Ministry of Education, the order of themes and topics overlap with the Ministry of Education and the content is appropriate for the principle of progressivity as well as Morpa campus' having audio and visual units facilitates memorability. The disadvantages of Morpa Campus are that it teaches topics superficially and doesn't provide in-depth knowledge and contributes to the research deficiently whereas the advantages of it are that it uses a language that children can understand, it is clear and enriches the content of the lesson.

Keywords: morpa campus, e-learning, web based training, science education, teaching

\section{INTRODUCTION}

Education is intimately related to cultural values and customs protected by every country (Gülcan, 2010), and it is a process that directly influences individual and communal living. The countries that reach a definite level of development give priority to education in innovation and development movements (Kaya, 2002). Development of a country is possible when the people that live in that country are educated; skills that are appropriate to the goals of the country and realities of the world are built; new technologies are developed and these technological developments are benefited at every field (Türk, 1999).

There is a big need for the individuals who are equipped with new attitudes and values to follow the developments on a global scale and to benefit from these developments (Tezcan, 2002). 
Nowadays, when the change is rapid, the need of people to education for keeping in step for this change is increasing every passing day. The proportion of scientific and technological developments has increased and this change has made itself evident at manufacturing and service fields (Genç, 2005). Information that is the most precious entity the societiey has and sharing of this has been one of the most important factors of globalization along with technological developments (Dilmen, 2004).

The institutions that do not want to get out of date are in the position of preparing their employees to ongoing developments. Getting information and savings quickly, adaptation of employees to rapid changes is provided with e-learning (Duran, Önal, \& Kurtuluş, 2015).

E-learning and web based education are learning and knowledge management, they are carried out by internet connection (e-nocta academy, 2015). E-learning has some advantages; it is colorful and entertaining, it is flexible in regard to time and place, its results are evaluable, it is supportive to classroom activities, table of contents are accessible again and again, people at different geographical parts can benefit from it at the same time or at different times, person can individualize his/her learning material according to his/her learning requirements, paper waste is prohibited (Noe, 2009, enocta academy, 2015, Aslan, 2006, Pura \& Aslan, 2015). Moreover, it plays an important role on equating communication level between student and teacher, giving equal rights to everyone, increasing motivation on people, ensuring psychological relief (Pura \& Aslan, 2015;3). Generally, these types of studies are cheaper than the real studies (Maiers, 2012)

E-learning has been gradually become widespread by means of giving time and place flexibility to students, giving variety to teaching and communication methods, supplying with education needs at broad and mountainous regions (Pituch \& Lee, 2006). Considering these advantages, it is seen that business world and educational institutions seriously invested in it. It is seen that especially USA is gradually increasing these investments. Foundations and technology should be sufficient, to reach success at elearning activities. Any e-learning strategies cannot be successful without sufficient internet connection (Sanderson, 2002; Aslan, 2006).

A basic characteristic of learning environments is design methodology. The lessons, programs and learning objects that can be reached at online learning environments can be learned by teacher leadership or can arrange his/her own speed by himself/herself or can manage himself. Online learning environments have 3 basic characteristics (Moore, Dickson-Deanee, Galyen, 2011).

Instructor-led learning: An instructor directs students with a content of necessary instructions. At the learning environment like this type, the instructor controls the speed and order of teaching and all of the students participate to the same learning activities at the determined times (Moore, Dickson-Deanee, Galyen, 2011).

Self-paced learning: That is an explanation used for self-learning environments; it is the environments providing learning favorably to the individuals' own learning speed and 
times at the same time according to their places. This mode of learning provides autonomy to the learner to progress in his/her own speed (Rhode, 2009).

Self-directed learning: It is a learning mode that the learner has his/her own learning responsibility, the learners manages himself in terms of cognitive and contextual learning (Moore, Dickson-Deanee, Galyen, 2011).

E-learning requires motivation and self-discipline. It requires well reading and writing skills. Sufficient and appropriate time should be allowed (Nagarajan, Wiselin, 2010). Also, it requires digital literacy, because it is online (www. Learning.com/digitalliteracy).

It is seen that a lot of studies are conducted searching application of e-learning materials at classroom and outside of classroom in terms of various factors. Some studies show that when the instructor adds e-learning material to his/her lesson the students with different learning styles are supported (Holley \& Boyle, 2012; Ilgar, 2013; Tozmaz, 2011) and some studies show that these materials increases the success of student (Tran et al, 2014; Mironova et al, 2015; Pituch \& Lee, 2006). Some studies make reference to opinions of teachers, teacher candidates and students related to application of e-learning (Genç, 2015; Doğan \& Ar1, 2015; Dikbaş, 2006, Duygu \& Uluuysal, Dindar 2013).

Contribution of technological equipments to education is stated in many national and international studies (Sarı, \& Akbaba Altun, 2015). The teachers who will use technology purposefully and efficiently should be competent on this topic. Coppola (2004) sees application of technology as a waste of time, if the teacher is inadequate at using educational technology.

It is seen that electronic learning devices that can be used in and out of the classroom for primary school teachers and students have increased in company with Fatih Project and developing technology. The Ministry of Education presents these materials at EBA (http://www.eba.gov.tr) environment for the teachers to use free of charge. Consequently, consideration of Morpa Campus which is a technological learning environment according to the teacher opinions within these efforts produced for a more qualified education will supply feedback for the users, education software developers and training directors.

The main purpose of this study is to determine the effects of Morpa Campus which is an e-learning application on science education according to the opinions of teachers. In the direction of this general purpose; the sub-purposes are as follows;

1. What are the opinions of teachers on the effects of Morpa Campus on science lesson at primary schools regarding realization of the attainments?

2. What are the opinions of teachers on effects of Morpa Campus regarding content size of science lesson at primary schools?

3. What are the opinions of teachers on effects of Morpa Campus on learning and teaching process at science lessons at primary schools?

4. What are the opinions of teachers on the effects of Morpa Campus regarding assessment dimension at science lessons at primary schools?

5. What are the opinions of teachers on the effects of Morpa Campus on students? 
6. What are the opinions of teachers on the advantages of Morpa Campus on teachers? 7. What are the opinions and suggest of teachers on development and use of Morpa Campus?

\section{METHOD}

\section{Research Design}

A descriptive model is used because this study is given on to determine the effects of Morpa Campus which is an e-learning application on teaching science lessons at primary schools according to the teacher opinions. Qualitative research model is benefitted from data collection, analyzing and interpretation. Qualitative search is the study in which a qualitative process is monitored that qualitative data collection methods such as observation, interview and document analysis are used (Yıldırım \& Şimşek, 2006). From these methods, interview is preferred at this study.

\section{Study Group}

Study is carried out with class teachers working at central primary schools in Ankara. Study group of this survey is determined according to purposeful sampling method. The teachers that create the study group of the survey are determined from two typical primary schools that resemble to other plenty of schools and having middle social economic class and its opportunities. The data obtained from the teachers selected from the teachers who use the Morpa Campus application in their lessons are also capable of giving information to other teachers. Sample is determined according to objective based situation sampling method in quantitative studies (Yıldırım \& Şimşek, 2006, Patton, 1987). Moreover; easily accessible sampling method is used because working on a familiar sampling will bring speed and practicability to the study while communicating with schools and teachers (Yıldırım \& Şimşek, 2006). In consequence of all these considered points, the sample of this study consists of 16 teachers who are using Morpa Campus application.

\section{Data Collection}

Open ended semi- structured interview questions are prepared and implemented to receive opinions of participants about Morpa Campus application. 3 different expert opinions are consulted; pilot interviews with teachers are conducted to test the clearness of interview questions for the purpose of examining semi structured interview form (interview questions, alternative questions and probes) prepared for the teachers. After expert opinions and pilot interviews, interview form is put into final form. At interviews, the questions at interview form are addressed to the participants one by one. The teachers who accept the interview among the teachers who use Morpa Campus application at their lessons are included to study group on voluntary basis by researchers. It is guaranteed that their identity information will be kept private by getting appointments from the teachers who are taking a part in working group, clarifying the aim of the study, presenting sample questions from the interview. Researchers had interview with voluntary teachers who made an appointment between the dates $01^{\text {st }}$ 
December 2016 - 30 ${ }^{\text {th }}$ December 2016. The talks are recorded to tape recorder, and then they are put down on paper by deciphering.

\section{Analysis of Data}

In the analysis phase of data, the answers given to interview questions prepared in accordance with the sub questions of the study are analyzed by using themes and codes put into final form after investigating the answers though ahead and during the investigation.

Collected data is analyzed by descriptive analysis technique. Recorded data is textualized and textualized data is placed into a matrix consisting of themes and interviewee dimensions. Data on matrix is coded and repetition frequency of data is checked. Findings organized accordingly are presented in form of frequency and percentage table. Acquired findings are supported by quoting from the coded answers that class teachers gave to the questions. In the study, code names are used instead of real names of the teachers while giving place to teacher opinions.

\section{FINDINGS}

At this section, findings regarding this study are dealt with considering sub-purposes.

1. The Opinions of Teachers on the effects of Morpa Campus on science lesson at primary schools regarding realization of the attainments?

The Opinions of Teachers on the effects of Morpa Campus on science lesson at primary schools regarding realization of the attainments are gathered at 4 categories under attainments theme (Table 1). These categories are determined as accordance with the attainments (15 people), sensation of attainments with sense organs (15 people), supporting of attainments ( 8 people), and realization of attainments ( 1 person).

Table 1

The Opinions of Teachers on the effects of Morpa Campus on science lesson at primary schools regarding realization of the attainments?

\begin{tabular}{llc}
\hline Theme & Categories & Frequency (f) \\
\hline \multirow{4}{*}{ Attainments } & Accordance with the attainments & 15 \\
\cline { 2 - 3 } & Sensation of attainments with sense organs & 15 \\
\cline { 2 - 3 } & Supporting of attainments & 8 \\
\cline { 2 - 3 } & Realization of attainments & 1 \\
\cline { 2 - 3 } & Total & 39 \\
\hline
\end{tabular}

Some statements of teachers who have participated to the study related to "accordance of attainments" are given as follows;

"Morpa Campus is in accordance with mathematics lesson curriculum at primary schools (...) Unit, topic and theme are parallel. It is parallel with experiments and attainments. ." (T2) 
"It is really favourable from the point of supporting basic attainments of National Education. Unit attainments and lesson attainments are already in accordance. They are in order. It is proceeding cohesively with the attainments of National Education without entering into too much detail" (T3)

Almost all of the teachers state that Morpa Campus is in accordance with attainments and attainments are appealing to sense organs. Some statements of teachers who have participated to the study related to "sensation of attainments with sense organs" are given as follows;

"The child himself wants to participate and speak seeing at the same time hearing. The student is more willing specially while doing experiments, at the exercises and activities or games for example sudoku, intelligent games and extra mental games. Because verbal lecture is going for nothing in my opinion, it is more beneficial because it appeals to more than one sense organs." (T2)

"We are lecturing to the students. The visuals are remembered easily... I am pleased with Morpa Campus because it is auditory and visual (...) We are having difficulty in finding materials and preparing visuals rather than planning the lesson. We should either do cut and paste or the students should do research at home. Every child does not have the opportunity to search. Or they cannot search intended level. But, they are learning more about how it is done because they are seeing that topic both as auditory and visual (...) Because it is auditory and visual making the students understand topic more quickly. That is to say, perception of the students is better because it contains visual statements with oral statements, it contains visuals or films appropriate for the age of the students. It expresses understandably. It is beneficial for the students to solve the questions both by seeing and hearing. He is reading, and then interpreting. I am reading some of them. It is already visual. If it is visual, it is more beneficial." (T5)

Half of the teachers who participated the study state that Morpa Campus supports the attainments of science lesson at primary schools. Some statements about "supporting of attainments" are given below;

"There are good examples in terms of visual materials. They are prepared as supportive of the attainments. Children comprehend the topic before I tell the lesson when I firstly open from there at science or the other lessons. Topics are step by step, that is good."(T6)"

"It is supporting the basic attainments of National Education. There is no problem because they have prepared the question according to the attainments. That is to say, there are not so many questions; there are questions according to the attainments." (T12)

2. Opinions of teachers on effects of Morpa Campus regarding content size of science lesson at primary schools

Opinions of teachers on effects of Morpa Campus regarding content size of science lesson at primary schools are given at table 2 . 
Table 2

Opinions of teachers on effects of Morpa Campus regarding content size of science lesson at primary schools

\begin{tabular}{lll}
\hline Theme & Categories & Frequency (f) \\
\hline \multirow{5}{*}{ Content } & Accordance of content & 13 \\
\cline { 2 - 3 } & Sciolism (No deepening) & 12 \\
\cline { 2 - 3 } & Enriching content & 8 \\
\cline { 2 - 3 } & Inadequacy of contribution to study & 6 \\
\cline { 2 - 3 } & Directing to study & 2 \\
\cline { 2 - 3 } & Explanation of topic & 1 \\
\cline { 2 - 3 } & Deepening & 45 \\
\cline { 2 - 3 } & Total & 3 \\
\hline
\end{tabular}

As it is seen at table 2 opinions of teachers on effects of Morpa Campus regarding content size of science lesson at primary schools are at 7 categories under content theme (Table 2). These categories are determined as accordance of content (13 people), sciolism (12 people), enriching content ( 8 people), inadequacy of contribution to study (6 people), directing to study ( 3 people), explanation of topic ( 2 people), and deepening (1 person).

Opinions of teachers on effects of Morpa Campus regarding content size of science lesson at primary schools are as follows:

"It is coherent with the content of the lesson. It is sometimes ahead, it is sometimes after. The order may be problematic but books are generally followed."(T5)

"It is a big advantage that it is lecturing the topic at a level that the students can understand." (T7)

"It is not treating a subject deeply. Topics are as a summary. Details can be dilated upon more. Topics are superficial. We were doing this: when we want to summarise the topic, in terms of looking the topics again at the end of the lesson, we were using it by way of repetition. It can be used like that because it is not detailed." (T15)

"I don't think that it is giving the lesson in a detailed way but a language that students can understand is used." (T1)

According to the teacher opinions; Morpa Campus presents information that can be used mostly as summary and repetition, even though some ordering problems are seen. This aspect of Morpa Campus is powerful, it is understood from the teacher opinions that Morpa Campus is not such as to support investigation and deepening skills of students.

The citations below support this view;

"There are no videos backed up from other places. But it is an adequate level compared to our school level. It is superficial. If all the students become a member at their homes, if they benefit from it at their home, it may be insufficient but, using as a repetition after lecturing is sufficient. If it is so detailed, we may not manage our time." (T1) 
"It is not so detailed. It is lecturing the lesson completely. That is to say, the children can understand the topic. It is enriching the content."(T7)

"It is directing the students to survey with short questions. It is directing to think. They are so good. It is lecturing the lesson, and then asking a question. After taking the answers from the students, we are providing continuance of the lesson." (T4)

"Actually it has no contribution to search or guidance. It is just for reinforcement. Think about reproduced questions form of evaluative questions they are alike." (T1)

3. The opinions of teachers on effects of Morpa Campus on learning and teaching process at science lessons at primary schools

The opinions of teachers on effects of Morpa Campus on learning and teaching process at science lessons at primary schools are at 8 categories under the theme contributions to the activities at the lesson (Table 3 ). These categorizes are determined as opportunity to reinforcement (15 people), game experiment puzzle (12 people), supporting the activities at the lesson (10 people), difficulty of individual activity ( 8 people), feedback and correction ( 7 people), active participation (6 people), opportunity of individual activity (3 people), opportunity of repetition (3 people).

Table 3

The opinions of teachers on the effects of Morpa Campus on learning and teaching process at science lessons at primary schools

\begin{tabular}{lll}
\hline Theme & Categorizes & Frequency (f) \\
\hline & Opportunity to reinforcement & 15 \\
\cline { 2 - 3 } & Game experiment puzzle & 12 \\
\cline { 2 - 3 } Contributions to the & Supporting the activities at the lesson & 10 \\
\cline { 2 - 3 } activities at lesson & Difficulty of individual activity & 8 \\
\cline { 2 - 3 } & Feedback and correction & 7 \\
\cline { 2 - 3 } & Active participation & 3 \\
\cline { 2 - 3 } & Opportunity of individual activity & 3 \\
\cline { 2 - 3 } & Opportunity of repetition & 64 \\
\hline
\end{tabular}

Some opinions on the effects of Morpa Campus on learning and teaching process at science lessons are given below:

"I am lecturing. After telling the lesson I go back to Morpa Campus, I am making them watch the videos.After I have traced it, I am practicing it because it is healthier in terms of reinforcements to tell and then to follow. (...)It provides a hundred percent reinforcement because it allows me to reinforce visually repeating what I'm saying. (...)When I see them superficially there, they have reinforced my statements more importantly and allow them to apply the subject better and healthier." (T8)

"Experiments are good. I mean, Children see themselves the experiments we can not do. There are puzzle activities in the reviews section.We do them together. There are games again.Leaving the games open sometimes in the classroom and 
in the breaks outside the classroom, they are concentrating on that game instead of fighting. "(T7)

"The children are actively involved because Morpa Campus is suitable for their level. So it catches the classroom level.As a result of active participation, children become more self-confident. Reinforcement is increasing. It has contributions to feedback and correction all." (T1)

According to teacher opinions it is seen that Morpa Campus provides feedback opportunity to science lessons at primary schools, it contributes to lessons with games, experiments and puzzles and it supports the activities at lesson."

4. The opinions of teachers on the effects of Morpa Campus regarding assessment dimension at science lessons at primary schools

The opinions of teachers on the effects of Morpa Campus regarding assessment dimension at science lessons at primary schools are at 4 categorized(Table 4$)$ under the theme assessment. These are determined as success (10 people), tests (10 people), recording success (6 people), and feedback (4 people).

Table 4

The opinions of teachers on the effects of Morpa Campus regarding assessment dimension at science lessons at primary schools

\begin{tabular}{llc}
\hline \multirow{2}{*}{ Theme } & Categorizes & Frequency (f) \\
\hline & Success & 10 \\
\cline { 2 - 3 } Assessment & Tests & 10 \\
\cline { 2 - 3 } & Recording success & 6 \\
\cline { 2 - 3 } & Feedback & 4 \\
\cline { 2 - 3 } & Total & 30 \\
\hline
\end{tabular}

Some statements on the effects of Morpa Campus regarding assessment dimension at science lessons at primary schools are given below;

“(....) So it helps to add indifferent students to lessons, to increase their success.I believe it will be more successful if everyone has it at home. There is a group, especially on the lower level.There is a group of children who learn by doing for the visual students at the bottom.It will be very useful for them. (....)There is an increase; interest is more than that anyway. For example, I used it in science class. They were looking forward to that lesson. "(T14)

"Better for the child I think the success is increasing,those who enter there are more successful than others who work there when compared to the others ... It is effective in student success. Because the child is more pleased to see it visually rather than seeing book.The student wants to see and listen. "(T9)

"At the end of Morpa campus topics, there are questions of evaluation. After I told you about the subject, there are questions about the evaluation of the achievement just like a short ten questions after I have watched the subject.I am applying this to the class and I think that you can increase your success by solving the questions and taking back the feedback."(T3) 
It is seen that while the majority of the teachers stated that the Morpa Campus is boosting success, some of the teachers did not record success in some areas. The following quotations support this view.

"We follow the students. It does not give much clue about success, how many of its students did him or did it with his parents. Sometimes they do it together and we do not know it. "(T15)

"I cannot record success because everyone is not registered. One or two students who are cheek by jowl with computer." (T10)

\section{The opinions of teachers on the effects of Morpa Campus on students}

When asked as "What are the effects of using Morpa Campus educational software from the point of students, they are at 5 categorizes under benefits for the students theme (Table 5). These are attention (12 people), participation (6 people), motivation (7 people), communication ( 5 people) and self-confidence ( 2 people).

Table 5

The opinions of teachers on the effects of Morpa Campus on students

\begin{tabular}{lll}
\hline Theme & Categorizes & Frequency (f) \\
\hline \multirow{4}{*}{ Benefits for the students } & Attention & 12 \\
\cline { 2 - 3 } & Motivation & 7 \\
\cline { 2 - 3 } & Participation & 6 \\
\cline { 2 - 3 } & Communication & 5 \\
\cline { 2 - 3 } & Self-confidence & 2 \\
\cline { 2 - 3 } & Total & 32 \\
\hline
\end{tabular}

Direct citations related to the benefits for the students are given below;

"Only when I tell the lesson cannot attract attention on a person basis this applies to every teacher but visually it attracts more attention to the children because it is visual. There are [Morpa Campus] examples of daily life so much overlap with the daily life can see more attention (....)There is an increase in interest and attitudes towards the course. "(T8)

“"(...) I think it's a lot more attentive. I use it all the time.Students are already entering the attended mode immediately after the projection is opened.They are curious about what will appear on the screen.This is very important for us in this age group(...) The most important feature of this age group is to provide participation, keeping interest alive. Interest is recovering quickly when we are opening the Morpa campus when the interest is fully reduced." (T16)

"Communication is rising a lot. The questions and activities are not difficult; it is not difficult, so even a passive student can do it. When it is done, the teacher is communicating with the class.This increases the motivation of the student,as communication progressively increases, increasing participation, they become more motive to the lesson." (T1)

It is seen that visibility of the Morpa Campus, daily samples of the given samples to increase the participation and motivation of attention. 


\section{The opinions of teachers on the advantages of Morpa Campus on teachers}

When asked as "What are the effects of using Morpa Campus educational software from the point of teachers, they are at 5 categorizes under benefits for the teachers theme (Table 6). These are make the lesson more fun (13 people), increase participation (6 people), ease of teaching difficult attainments ( 5 people), attract attention ( 3 people), classroom management (1 people) and saving time (1 person).

Table 6

The opinions of teachers on the advantages of Morpa Campus on teachers

\begin{tabular}{lll}
\hline Theme & Categorizes & Frequency (f) \\
\cline { 2 - 3 } & Make lesson more fun & 13 \\
\cline { 2 - 3 } & Increase participation & 6 \\
\cline { 2 - 3 } Advantages for the teachers & Ease of teaching difficult attainments & 5 \\
\cline { 2 - 3 } & Attract attention & 3 \\
\cline { 2 - 3 } & Classroom management & 1 \\
\cline { 2 - 3 } & Enrichment of lesson & 1 \\
\cline { 2 - 3 } & Saving time & 30 \\
\cline { 2 - 3 } & Total & \\
\hline
\end{tabular}

Direct citations related to the advantages for the teachers are given below.

It is seen that being audiovisual and visual in Morpa Campus makes the lesson fun with songs, animations, puzzles, experiments and stories. The following quote supports this view;

"Kids get more fun. They say; my teacher, open it (Morpa Campus). There is music and visuals.Apart from that, there is story-style expression.For this reason, children play when they see it.(...) makes the lesson fun.At least the children are not bored. "(T9)

"There is sound, there is visual.It is explained in a fun way with the songs....It makes the lesson fun. "(T7)

"The curriculum is fun because it's done properly and given in animations." (T4)

It is seen that the frequent use of Morpa Campus makes the lesson boring and reduces participation. The following quote supports this view.

"If they enjoy the subject and narration, [the attendance to the lesson] is increasing. But sometimes they can be bored. There may be situations where attendance is low in this environment. Sometimes we are surprised. "(T6)

It is seen that teachers use Morpa Campus specifically for the gains they are having difficulty to teach. Being a ready resource for students, enriching the lesson, prolonging attention span, saving time in lectures and facilitating classroom management in crowded classrooms are the advantages for the teachers. The following quotations support this view. 
"(....) direct starting with Morpa Campus in difficult situations is beneficial to me in terms of motivating children to start on the table.(...) If it is difficult to explain to the children, I just open up on the Morpa Campus. We work that way.They are very successful. "(T3)

"A great convenience to us, a great resource for teachers,ease. When you use plainly, you can keep the attention of children long and tell the lesson very comfortable.You can enrich with events.I mean, I'm very satisfied. "(T1)

"Because the children pay more attention, there is not much noise in the lesson.So I think that the teacher will be more successful in managing the class.(...) I do not have a lot of managing problems, but especially because of the attention of the crowded classrooms..." (T14)

"I love Morpa Campus very much.It benefits me when I am able to get to the topic instantly without losing any time at the lesson. It gives a great advantage that it tells the topics in the level that children understand. "(T16)

7. The opinions and suggestions of teachers on development and use of Morpa Campus The opinions of teachers on development and use of Morpa Campus are at 8 categories under suggestions theme. These are the number of samples should be increased, lectures must be enriched, the number of animations should be increased, should not be standard lectures, classroom management, research-oriented studies should be increased, visuals should be enriched, scientific activities should be increased and mutual interaction should be increased.

Table 7

The opinions and suggestions of teachers on development and use of Morpa Campus

\begin{tabular}{llc}
\hline Theme & Categorizes & Frequency (f) \\
\hline \multirow{4}{*}{ Suggestion } & The number of samples should be increased & 10 \\
\cline { 2 - 3 } & Lectures must be enriched & 3 \\
\cline { 2 - 3 } & The number of animations should be increased & 2 \\
\cline { 2 - 3 } & Should not be standard lectures & 2 \\
\cline { 2 - 3 } & Research-oriented studies should be increased & 2 \\
\cline { 2 - 3 } & Visuals should be enriched & 2 \\
\cline { 2 - 3 } & Scientific activities should be increased & 2 \\
\cline { 2 - 3 } & Mutual interaction should be increased & 24 \\
\cline { 2 - 3 } & Total & \\
\hline
\end{tabular}

It is seen that teachers' greatest criticism of the Morpa Campus is that the number of samples supporting the activities on the ground is insufficient. The high cost and the low number of scientific activities are among the critics. Quotations from teacher opinions are given below.

"Samples are sometimes simple to us.But to address the whole class, to address the students whose level is low, we have to open Morpa Campus. During this time, of course, the other students are bored. (...)Sample number should be increased.For example, we want to open questions about the subject, there are a couple of questions." (T6) 
"I wish it was free to the students. I think that way.It's because the kids on our side are not in good shape. Or the cost can be reduced. It can be a small amount."(T13)

"When there is content as if the students are interacting, they get more pleasure.They feel they also participate.It would be better if more animations were included and interacted.The expression of Morpa Campus is always the same. I look at other sites, I bring them with flash and I use them also.There are presenters with songs.There is a standardized technique on the Morpa Campus.The whole thing is the same....Visuality can be improved a little more.The activities can be a little more game or experiment instead of question and answer.It may be a bit heavier in the scientific direction. It can prompt the students to research." (T16)

The following opinion about the use of Morpa campus is out of the category, it attracts notice;

"The children of more conscious parents are using Morpa Campus. These children are often successful children. It is a little related to the family, related to internet usage. Most of them do not have internet at home. They are following Morpa Campus in the way we used it in classroom. But there is an increase in the use of conscious parents." (T01)

\section{DISCUSSION}

It is seen that Morpa Campus is compatible with the main attainments of the Ministry of National Education, theme and subject sequence overlap and are suitable for the phasing of topics. Moreover, the fact that Morpa Campus is audiovisual facilitates the memorability of the issues. Visuality and audibility make it easier to learn because it stimulates the sense organ and attracts the attention and care of the learner (Güngördü, 2003). The more the number of senses addressed in the teaching process, the more effective it will be in learning (Küçükahmet, 2008: 53). In particular, using animations in the learning environment, appealing to more than one sensory organs makes understanding and transfer of information considerably easier (Kahyaoğlu, 2011). When the literature is examined, it is seen that there is more success in the subjects that are processed using animations (Daşdemir \& Doymuş, 2012). (Bayram \& Koçak, 2013; Daşdemir \& Doymuş, 2012; Ayvacı \& Abdüsselam, Abdüsselam, 2012).

It is seen that Morpa Campus is compatible with content. While superficial information and not giving in-depth information, inadequacy of research contribution are disadvantages of Morpa Campus, enriching the content of the course, use of a language that children can understand and clearness are advantages.

Teachers use Morpa Campus as a supporting element, not as a basic tool. Cengiz (2010) suggests that teachers use TTNET Vitamin only in drawing subjects in the research of teachers of TTNET Vitamin use. Tutar (2015) says that in the evaluation of teachers' opinions for the Educational Information Network (EBA) site, teachers do not use EBA frequently but they have the idea that it is a useful, effective and productive site. It is seen that Morpa Campus offers course reinforcement, offers lessons with activities such 
as games, puzzles and experiments. It is stated in an investigation conducted by Alabay (2015) for the use of EBA (Educational Information Network) that the least used content of the teachers is game, experiment applications and project applications.

It is stated that most students do not have a computer and internet connection at home or because of the cost of Morpa Campus, most students do not use Morpa Campus at home and they do not have the opportunity to do individual exercises. According to the TUIK data, the rate of the Internet access facilities in Turkey is $69.5 \% .59 .5 \%$ of the families who do not have internet access at home stated that they do not need internet, $44.7 \%$ of them do not know internet usage sufficiently (TUIK, 2015).

It is seen that Morpa Campus has a positive contribution to success, the subjects are assessed by evaluation of the attaintment. In the researches conducted, it was concluded that the computer assisted teaching method is more effective than the traditional teaching methods in terms of access, permanence and success (Demirer, 2006, Karaoğlu, 2008). It is stated that the success is not recorded because the majority of the students do not have membership. It can be said that Morpa Campus contributes to the students' interest, motivation and participation, and helps students to communicate during the course. It is seen that the self-confidence of the students who attend the course is increased. In the case of continuous use, it is expressed that the students are bored after a certain period of time and the interest and participation decrease.

While the use of Morpa Campus makes the lesson fun, it also increases the participation in the lesson. It also appears to have contributed to the teachers' teaching of difficult attainments .

It is emphasized by the majority of the teachers that the sample number should be increased especially in Morpa Campus.

\section{SUGGESTION}

The research can be done especially in the classrooms where all students use the Morpa Campus. Opinions about Morpa Campus can be obtained according to the using computers frequency of teachers. In addition, observations can be made in the classrooms in which they are used and can be examined in detail for each of the courses.

\section{REFERENCES}

Alabay, A. (2015). Ortaöğretim ögretmenlerinin ve ögrencilerinin EBA(Ĕ̈itimde Bilişim A $\left.\breve{g}_{l}\right)$ kullanımına ilişkin görüşleri üzerine bir araştırma. [A research into secondary education teachers' and students' views on EBA] Unpublished Master's Thesis, İstanbul Aydın Üniversitesi, İstanbul.

Aslan, O. (2006). Ögrenmenin yeniyolu: E-öğrenme. [New Way of Learning: ELearning]. Firat Üniversitesi Sosyal Bilimler Dergisi, 16(2), 121-131, Elaz1g-2006

Ayvac1, H. G., Abdüsselam, Z., \& Abdüsselam, M. S. (2012). Animasyon destekli çizgi filmlerin fen öğretiminde kavramsal anlamaya etkisi: 6 . sınıf kuvveti keşfedelim konusu örneği. X. Ulusal Fen ve Matematik Eğitimi Kongresi. 27/06/2012 - 30/06/2012. Niğde 
Bayram, K., \& Koçak, N. (2013). Öğretmen adaylarının genel kimya dersindeki erişilerine ve kalıcılık düzeylerine animasyon uygulamalarının etkisi. TurkishStudies International Periodical For The Languages, Literature and History of Turkish or Turkic 8(12), 167-177.

Cengiz, D. (2010). MEB öğretmenlerinin TTNET Vitamin kullanımında Uşak örneği. [Teacher's use of TTNET Vitamin: A sample of Uşak ]. IX. Ulusal Fen Bilimleri ve Matematik Ĕ̈itimi Kongresi, İzmir, 87.

Coppola, E, M. (2004). Powering up: Learning to teach well with technology, Retrieved 11 November, 2015 from http://www.citeulike.org/user/etec533ta/article/366384.

Daşdemir, İ., \& Doymuş, K. (2012). 8. sınıf kuvvet ve hareket ünitesinde animasyon kullanımının öğrencilerin akademik balarılarına, öğrenilen bilgilerin kalıcilığına ve bilimsel süreç becerine etkisi.[The effect of the use of animation in "Force and Movement" unit in the $8^{\text {th }}$ grade on the students' academic achievement, persistence of learned knowledge and scientific process skills]. Eğitim ve Öğretim Arastırtımalar Dergisi, 1(1), 77-87.

Demirer, A. (2006). ilköğretim ikinci kademede bilgisayar destekli fen bilgisi ögretiminin öğrenci başarısına etkilerine ilişkin bir araştırma: Şehit Namık Tümer ilköğretim okulu örneği. [A research on the effects of students' success computer assisted to science teaching six to eight grades of primary schools (in Sehit Namik Tumer Primary School sample)] Unpublished Master's Thesis, Dicle Üniversitesi, Diyarbakır.

Dilmen, N. E. (2004). Bireyselleşen Küre, Küreselleşme, Temel metinler, Ekonomi, Siyaset, Kimlik, Kültür, Medeniyet, [Individualizing Sphere, Globalization, Basic Texts, Economy, Politics, Identity, Culture, Civilization] ,Editör: B. Kudret, Orion Kitapevi s. 99-120

Dikbaş, E. (2006). Öğretmen adaylarının e-öğrenmeye yönelik tutumlarının incelenmesi. [Examining attitudes of preservice teachers' toward e-learning] Unpublished Master's Thesis, Dokuz Eylül Üniversitesi, İstanbul.

Doğan, B., \& Arı, G. (2015). Web tabanlı uyarlamalı zeki öğretim sistemleri ve örnek bir uygulama. [Adaptive web-based intelligent tutoring systems and an application] Eğitim ve Ögretim Araşttrmaları Dergisi (Journal of Research in Education and Teaching), 4(4).

Duran, N., Önal, A., \& Kurtuluş, C. "E-Öğrenme ve Kurumsal Eğitimde Yeni Yaklaşım Öğrenim Yönetim Sistemleri" [E-Learning and New Approach Learning Management Systems in Corporate Education] http://ab.org.tr/ab06/bildiri/165.pdf 11 Kasım 2015 tarihinde alınmıştır.

Duygu, S., Uluuysal, E, B., \& Dindar, M. (2013). Görsel algı kuramlarına dayalı etkileşimli bir öğretim ortamı tasarımı ve ortama ilişkin öğrenci görüşleri. Anadolu Journal of Educational Sciences International, 2013, 3(1), 47-66. 
Genç, Z., (2015, July). Usability of a web-based school experience system: Opinions Of It teachers and teacher candidates. (Edited: Nunes, M, B., Mcpherson, M.,) Proceedings of The International Conference e-Learning. Las Palmas de Gran Canaria, Spain.

Genç, S. Z. (2005). avrupa birliği eğitim programları ve türkiye, [european Union Education Programs and Turkey] Kazım Karabekir Eğitim Fakültesi Dergisi, 11, 317330.

Gülcan, M. G. (2010). Avrupa birliği ve eğitim, [European union and education]. Pegem A Yayıncilık, Ankara.

Güngördü, E. (2003). Öğretimde görsellik ve görsel araçlarda bulunması gereken özellikler, [Visuality in teaching and features to be found in visual instruments]. Milli Eğitim Dergisi, 157.

Güven, G., \& Sülün, Y. (2012). Bilgisayar destekli öğretimin 8.Sınıf Fen ve Teknoloji dersindeki akademik başarıya ve öğrencilerin derse karşı tutumlarına etkisi. Türk Fen Ĕ̈itimi Dergisi, 9(1).

Holley, D., \& Boyle, T. (2012). Empowering teachers to develop multimedia learning resources that support students' critical Thinking. European Journal of Open, Distance and E-Learning. Retrieved 4 Janulary, 2016 http://www.enocta.com/e-ogrenme-nedir/ sitesinden 11 Kasım 2015 tarihinde alınmıştır.

Ilgar, M. (2013).Yabancı dil olarak Türkçe öğretiminde e-öğrenim yoluyla kelime öğretimi. [Vocabulary teaching in teaching Turkish as foreign language by means of elearning] Unpublished Master's Thesis, Gazi Üniversitesi, Ankara.

Kahyaoğlu, M. (2011). İlköğretim öğretmenlerinin fen ve teknoloji dersinde yeni teknolojileri kullanmaya yönelik görüşleri. [The Views of Elementary Teachers on Using New Technologies in Science and Technology Teaching]. Eğitim Bilimleri Araştırmaları Dergisi, 1(1), 79-96.

Karaoğlu, A. (2008). Illköğretim bilgisayar derslerinde web tabanlı eğitimin öğrenci başarı düzeyine etkisi. [The effect of web-based education on the achievement level of computer course at primary level] Unpublished Master's Thesis, Bahçeşehir Üniversitesi, İstanbul.

Kaya, Z. (2002). Uzaktan eğitim[Distance education]. Ankara: Pegem A Yayınları.

Küçükahmet, L. (2008). Öğretimde planlama ve değerlendirme. [Planning and evaluation in teaching] Ankara: Nobel Yayın Dağıtım.

Maiers, A. (2015). How the online education system helps the students Retrieved 11 November http://www.angelamaiers.com/2012/11/how-the-online-education-systemhelps-the-students.

Mironova, O., Amitan, I., Vendelin, J., Vilipõld, J., \& Saar, M. (2015). Maximizing and personalizing e-learning support for students with different backgrounds and 
preferences. (Edited: Nunes, M, B., Mcpherson, M.,) Proceedings of The International Conference e-Learning. Las Palmas de Gran Canaria, Spain.

Moore, J. L., Dickson-Deanee, C., \& Galyen, K. (2011). E-Learning, online learning, and distance learning environments: Are they the same? Internet and Higher Education $14,129-135$.

Nagarajan P., \& Wiselin Jiji G. (2010). Online educational sysytem (e-learning). International Journal of $\mathrm{u}$ - International Journal of $\mathrm{u}$-and e-Service. Science and Technology Service, Science and Technology, 3(4).

Noe, R. A. (2009). Insan kaynaklarının eğitimi ve geliştirilmesi [Training and development of human resources]. İstanbul: Beta Basım.

Pituch, K, A., \& Lee, Y. (2006). The influence of system characteristics on e-learning use. Computers \& Education 47, 222-244.

Pura, T., \& Aslan K. (2015). Web tabanlı eğitimin verimliliğinin incelenmesi. [The effectiveness of web-based training] Öğretim Araştırmalarl Dergisi. (Journal of Research in Education and Teaching). 4(4), 1-7.

Rhode, J. F. (2009). Interaction equivalency in self-paced online learning environments: An exploration of learner preferences. The International Review of Research in Open and Distance Learning, 10(1). Retrieved 10 November 2015 from http://www.irrodl.org/index.php/ irrodl/article/view/603/1179.

Sanderson, P, E. (2002). E-Learning: strategies for delivering knowledge in the digital age. Book Review, Internet and Higher Education, 5 (2002), s. 185-188. Retrieved 20 April $2016 \quad$ from http://citeseerx.ist.psu.edu/viewdoc/download?doi=10.1.1.87.9116\&rep=rep1\&type=pdf.

Sarı, M. H., \& Akbaba Altun, S. (2015). Sınıf öğretmenlerinin Matematik öğretiminde teknoloji kullanımı üzerine nitel bir araştırma [A qualitative research on classroom teachers' technology use in mathematics teaching]. International Journal Of Eurasia Social Sciences, 6(19), 24-49.

Tezcan, M. (2002). Küreselleşmenin eğitim boyutu, [Educational Perspectives in Globalization] Ĕgitim Araştırmaları Dergisi, (6), 56-60.

Tran, B. X., Nguyen, Q. L. T., Nong, V. M., Maher, R. M., Nguyen, A. T., Nguyen, H. A. (2014). Student-centred Outcomes of an e-Learning Course on Public Health in Hanoi and New York. European Journal of Open, Distance and E-Learning. Retrieved 20 April 2016 from http://www.eurodl.org/materials/contrib/2014/Tran_et_al.pdf.

Tozmaz, G. B. (2011). E-öğrenme ders içerikleri için uygulanabilir öğretim tasarımı modeli geliştirme ve bir uygulama. [Development of an applicable instructional design model for e-learning course content and an application]. Unpublished Master's Thesis. İstanbul Üniversitesi, İstanbul. 
Tutar, M. (2015). Ĕğtim bilişim ăg (EBA) sitesine yönelik olarak ögrretmenlerin görüşlerinin değerlendirilmesi. [The evaluation of teachers' perceptions towards education information network] Unpublished Master's Thesis. Karadeniz Teknik Üniversitesi, Trabzon.

Tüik, (2015). $\quad$ Retrieved $20 \quad$ April 2016 from http://www.tuik.gov.tr/PreHaberBultenleri.do?id=18660.

Türk, E. (1999). Millî Ĕ̆̈itim Bakanlı̆̆ında yapısal değişmeler ve Türk eğitim sistemi. [Structural change in the Ministry of National Education and Turkish education system] Ankara: Nobel Yayıncılık.

Yıldırım, A., \& H. Şimşek, (2006). Sosyal bilimlerde nitel araştırma teknikleri. [Qualitative research techniques in social sciences]. Ankara: Seçkin Yayınları. 